\begin{tabular}{|c|c|}
\hline $\begin{array}{l}\text { MAR } 131998,20 \text {, ENGINEERING DATA TRANSMITTAL } \\
\text { Sta. } 37(2)\end{array}$ & 1. EDT $\quad 620803$ \\
\hline
\end{tabular}

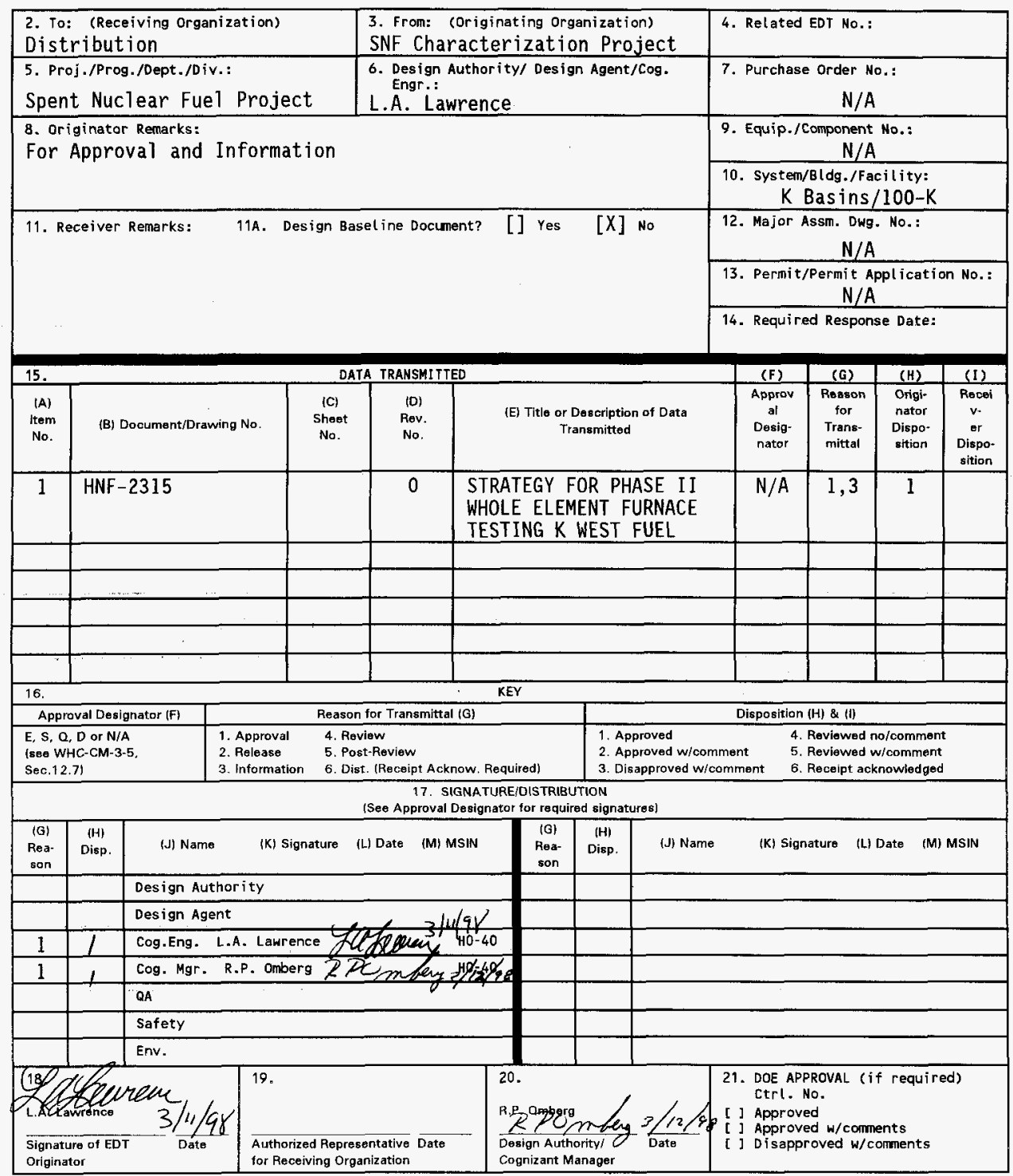

BD-7400-172-2 (05/96) GEF097 


\title{
STRATEGY FOR PHASE II WHOLE ELEMENT FURNACE TESTING K WEST FUEL
}

\author{
L. A. Lawrence
}

Duke Engineering \& Services, Hanford, Inc., Richland, WA 99352

U.S. Department of Energy Contract DE-AC06-96RL13200

\author{
EDT/ECN: $620803 \quad$ UC: 2070 \\ Org Code: 2T720 Charge Code: LB026 \\ B\&R Code: EW7040000 Total Pages: 15
}

Key Words: Strategy, Fuel Examinations, 105-K West, Spent Nuclear Fuel Project

Abstract: A strategy was developed for the second phase of the whole element furnace testing of damaged fuel removed from the $K$ West Basin. The Phase II testing can be divided into three groups covering oxidation of whole element in moist inert atmospheres, drying elements for post Cold Vacuum Drying staging tests, and drying additional $K$ West elements to provide confirmation of the results from the first series of damaged $K$ West fuel drying studies.

TRADEMARK DISCLAIMER. Reference herein to any specific comercial product, process, or service by trade name, trademark, manufacturer, or otherwise, does not necessarily constitute or imply its endorsement, recommendation, or favoring by the United states Government or any agency thereof or its contractors or subcontractors.

Printed in the United States of America. To obtain copies of this document, contact: Document Control Services, P.O. Box 950, Mailstop H6-08, Richland WA 99352, Phone (509) 372-2420;

Fax (509) 376-4989.
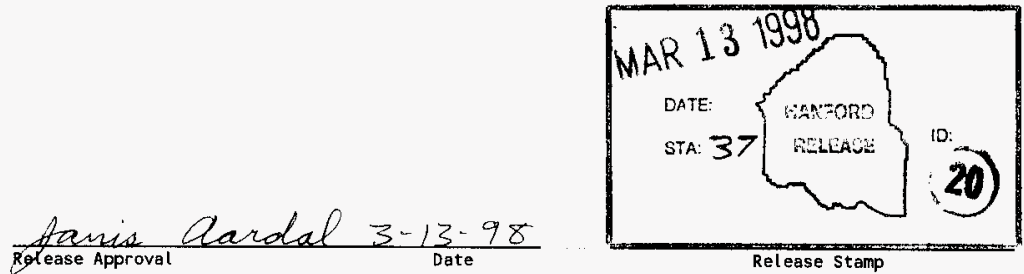

Rel ease Stamp 
HNF-2315, Rev. 0

STRATEGY FOR PHASE II WHOLE ELEMENT FURNACE TESTING K WEST FUEL

L. A. Lawrence

Duke Engineering \& Services Hanford, Inc.

March 1998 
Document Title: STRATEgY FOR PHASE II WHOLE ELEMENT FURNACE TESTING K WEST FUEL.

Prepared by: $3 / 11 / 98$

Approved by:

$3 \% 3 / 1 p^{r}$
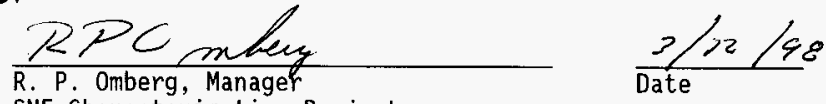

Approved by:

SNF Characterization Project

Approved by:

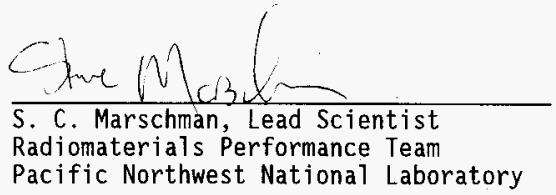

$\frac{3-12-98}{\text { Date }}$ Pacific Northwest National Laboratory

$\frac{3 / 12 / 98}{\text { Date }}$

T. A. Flament, Manager Process

Numatec Hanford Corporation

Approved by:

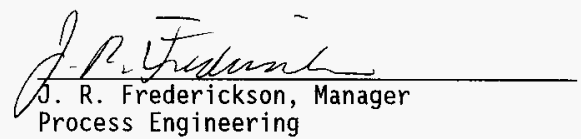

$\frac{3 / 12 / 98}{\text { Date }}$ 
HNF-2315, Rev. 0

\section{EXECUTIVE SUMMARY}

A strategy was developed for the second phase of the whole element furnace testing of damaged fuel removed from the $k$ West Basin. This document extends the initial plans developed for the examinations of the fifteen $K$ West fuel elements. The Phase II testing can be divided into three groups covering, oxidation of whole elements in moist inert atmospheres, drying elements for post Cold Vacuum Drying (CVD) staging tests, and drying additional $K$ West elements to provide confirmation of the results from the first series of damaged $K$ West fue 7 drying studies. Test $P l a n s$ and detailed Test Instructions will be prepared based on this strategy and appropriate Letters of Instruction. 
HNF-2315, Rev. 0

\section{CONTENTS}

1.0 INTRODUCTION .......................... 5

2.0 WHOLE ELEMENT FURNACE TESTING ............... . . 5

2.1 OXIDATION OF WHOLE ELEMENTS ........... 5

2.2 POST COLD VACUUM DRYING STAGING TESTS . . . . . . . . . 7

2.3 SERIES II DRYING TESTS ................... 8

3.0 PHASE II TEST MATRIX . . . . . . . . . . . . . . . . 9

4.0 PHASE II TEST SCHEDULE . . . . . . . . . . . . . . . 12

5.0 PHASE III fURNACE TESTING . . . . . . . . . . . . . . . 12

6.0 REFERENCES . . . . . . . . . . . . . . . . . . 13 
HNF-2315, Rev. 0

\section{LIST OF FIGURES}

1. Phase II Furnace Test Schedule . . . . . . . . . . . . . . . 11

\section{LIST OF TABLES}

1. Test Matrix for Oxidation Measurements in Moist Inert

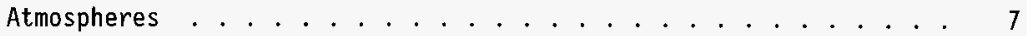

2. Phase II Test Matrix for Oxidation, Post Cold Vacuum Drying Staging, and Drying Studies ................ 9

3. K West Fuel Element Inventory . . . . . . . . . . . . . . . . 10 
HNF-2315, Rev. 0

\section{STRATEGY FOR PHASE II WHOLE ELEMENT FURNACE TESTING $K$ WEST FUEL}

\subsection{INTRODUCTION}

This plan establishes the strategy and specific tests to be conducted for the second phase of the whole element furnace testing of $K$ West fuel elements. The initial strategy for the examination of the fifteen $K$ West fuel elements contained only the first phase of the furnace testing (Lawrence 1997). The first phase furnace testing includes the initial calibration tests with undamaged fuel and the drying of five damaged $K$ West elements with differing degrees of degradation. This first series of tests is now complete and the next phase of testing has been developed to support the preparations of the Safety Analysis Report (SAR) and the process design for Cold Vacuum Drying (CVD).

\subsection{WHOLE ELEMENT FURNACE TESTING}

The whole element furnace testing can be divided into three groups of tests covering oxidation of whole element in moist inert atmospheres, drying elements for post CVD staging tests, and drying additional damaged elements for confirmation of results from the Phase I testing.

\subsection{OXIDATION OF WHOLE ELEMENTS}

A recent analysis of the oxidation rates in dry air for degraded $\mathrm{N}$ Reactor fuel suggests controlled reaction rate testing in the whole element furnace under moist inert atmospheres (Pajunen 1998). Results of the first two furnace tests with damaged fuel, i.e., Runs 3 and 4 (01iver 1998; $\mathrm{K} 1$ inger 1998) were evaluated for the reaction rates in dry air. Hydrogen release at temperatures below the decomposition temperature of metal hydrides, i.e., approximately $250^{\circ} \mathrm{C}$, were attributed to the oxidation of the exposed

fuel. From an estimate of the exposed fuel surface an integral oxidation rate for the element was obtained. Measurements of oxidation rates using this technique were generally in agreement with the rate equations adjusted by the Reactivity Enhancement factor (Lawrence 1998a) consistent with the ThermoGravimetric Analysis (TGA) measurements of damaged $K$ West fuel samples at low temperatures in dry air (Abrefah 1998).

The main objective of the oxidation tests is to determine oxidation rates on undisturbed surfaces, i.e., surfaces that were not cut or altered in the laboratory, in atmospheres close to the conditions expected in the Multiple Canister Overpacks (MCOs) during handling and CVD. Laboratory TGA measurements of oxidation rates for moist inert atmospheres are planned for small samples sectioned from the damaged regions of $K$ West fuel elements. These samples have as cut surfaces for the oxidation reaction. The whole element tests provide for scaling from gram size fuel samples for the TGA 
measurements to full size elements, i.e., kilogram, before handling metric tons of material in an MCO. One additional aspect of this whole element test is the issue of the propagation of the reaction in the element. This is very difficult to model and these tests will provide first time data on a whole element level.

Results of these tests will support the CVD SAR development as well as the process design. The current safety basis is completely dependent upon modeling the MCO behavior during drying. Theses tests will provide data to support the process modeling efforts in the areas:

- Hydrogen production

- Heat generation

- Fuel element condition following oxidation

- Integral effects of oxidation rates from TGA measurements with differing extents of fuel damage.

The data obtained from these tests that support the thermal modeling together with the whole element furnace drying data from Phase I, the TGA oxidation measurements, and the first article testing of MCOs will form the basis to demonstrate safe and efficient operation of the CVD for the Operational Readiness Review (ORR). include:

The consequence for the CVD design depending upon the test results

- Changes in process parameters such as temperature, drying cycle, helium flow rate, etc.

- Changes in safety class instrumentation and control system

- Revision to the number of bays in the CVD facility.

- Revisions to the runaway control strategy. It may be possible to change from an incredible accident scenario to one based on measurements of each MCO during the drying process to prevent the runaway reactions.

The main area of concern for the oxidation rates is the moist inert atmospheres. The next two whole element furnace tests will expand the measurements described above to consider moist inert atmospheres. These two tests will also focus on oxidation rather than on obtaining the measurements as a by product of the drying data. The oxidation rate will be evaluated by measuring the hydrogen generation rate in the furnace gas downstream of the element. Water vapor pressure will be measured in the downstream gas as well as the fission product gases xenon and krypton.

The two elements selected from the current $K$ West fuel inventory for the testing will include one with the minimal amount of damage and one that represents extensive fuel damage. The first damaged fuel element with minimal damage also has a fairly well defined exposed uranium surface for reaction. 
The test matrix from the oxidation tests is summarized in Table 1 . A calibration test with unirradiated $N$ Reactor fuel sections with known fuel surface area will be conducted to verify operation with the moist inert atmosphere before the damaged elements are tested. This first test also provides a point of reference for comparison to TGA measurements.

Table 1. Test Matrix for 0xidation Measurements in Moist Inert Atmospheres.

\begin{tabular}{||c|c|c|c||}
\hline $\begin{array}{c}\text { Furnace } \\
\text { Run } \\
\text { Number }\end{array}$ & $\begin{array}{c}\text { Element } \\
\text { Number }\end{array}$ & \multicolumn{1}{|c|}{ Element Condition } & \multicolumn{1}{c||}{ 0bjective of Test } \\
\hline \hline 8 & $\begin{array}{c}\text { Not } \\
\text { applicable }\end{array}$ & $\begin{array}{l}\text { Sections of an } \\
\text { unirradiated N Reactor } \\
\text { inner element }\end{array}$ & $\begin{array}{l}\text { System calibration with } \\
\text { unirradiated fuel with a } \\
\text { known surface area }\end{array}$ \\
\hline 9 & $\begin{array}{c}\text { 0309M } \\
\text { (Number 6) } \\
\text { Bottom half }\end{array}$ & $\begin{array}{l}\text { Breached lower half of } \\
\text { element dryed in furnace } \\
\text { Run 3 }\end{array}$ & $\begin{array}{l}\text { Oxidation with minima T } \\
\text { exposed fuel equal to } \\
\text { approximately one outer fue1 } \\
\text { element cross sectional area }\end{array}$ \\
\hline 10 & $\begin{array}{c}\text { 6513M } \\
\text { (Number 1) }\end{array}$ & Severe fuel damage & $\begin{array}{l}\text { 0xidation with an extended } \\
\text { amount of exposed fuel }\end{array}$ \\
\hline
\end{tabular}

The furnace test temperature cycle calls for three hold periods of 12 to 24 hours duration at $50{ }^{\circ} \mathrm{C}, 75^{\circ} \mathrm{C}$, and $100{ }^{\circ} \mathrm{C}$ with a temperature ramp rate of $0.5{ }^{\circ} \mathrm{C} /$ minute between the hold periods. Following the hold period at $100{ }^{\circ} \mathrm{C}$ the cycle will be repeated in reverse order. The moisture level in argon under vacuum conditions will be approximately 40 torr for temperatures of $50{ }^{\circ} \mathrm{C}$ and $75^{\circ} \mathrm{C}$ and approximately 80 torr for $75{ }^{\circ} \mathrm{C}$ and $100^{\circ} \mathrm{C}$.

The damaged elements, i.e., Runs 9 and 10 , will be subjected to a complete drying cycle similar to the temperature cycles for the furnace Run 3 through 7 (0liver 1998; Klinger 1998) following the oxidation run. These tests will explore the questions related to moisture and hydrogen release in elements that have been exposed to moist inert atmospheres compared to the baseline measurements in Runs 3 through 7 .

\subsection{POST COLD VACUUM DRYING STAGING TESTS}

Two damaged $K$ West outer fuel elements are to be monitored for gas generation at expected storage temperatures after CVD. A detailed analysis of the anticipated whole element pressurization of a storage container during this staging test showed expected pressure increases of approximately 20 psig at storage temperatures up to $150{ }^{\circ} \mathrm{C}$. The analysis showed the pressure to increase to a relatively stable value in approximately the first 30 days after CVD (Huang 1998). The analysis used the same modeling techniques that are being used for the complete MCOs. 
The test strategy calls for placing the damaged element in the whole element furnace for a complete CVD cycle. Following the CVD cycle the element will be subjected to a specified temperature ramp to the pre-selected temperature which will be no higher than $150{ }^{\circ} \mathrm{C}$. This allows the full capabilities of the whole element furnace to be utilized to monitor the initial pressure buildup (Ritter 1998a). This phase of the test in the whole element furnace is expected to take no more than the 30 days calculated with the model. Following this the element will be placed in a specially designed container for long term monitoring of the gas generation rates.

The long term storage container includes a device to aid in loading in the hot cell and centering the element in the container and provides for purging the container to control the gas environment (Ritter 1998b). Each container includes heat tape positioned in an annulus for temperature control monitored with thermocouple positioned on the element inner surface. A prototype was tested in the laboratory to verify that axial temperature gradients in the container were within acceptable limits. Individual pressure sensors are included for each container. Two vacuum valves provide an opportunity to periodically sample the gases as required and can control the gas inventory in the container should it exceed an as yet specified hydrogen inventory limit for the containers in the hot cells.

The two step process was selected for these tests for the following reason. The analysis suggests rapid gas generation for approximately 30 days after CVD with relatively stable behavior beyond the initial 30 day period. The whole element furnace has full capability to control temperatures and monitor the elements for gas generation as well as identify the species released with the Mass Spectrometer and Gas Chromatograph and is the preferred tool for these measurements. However, it was recognized that it would not be possible to limit the availability of the furnace during the long term portions of the test which may last several months. Planned drying tests for the whole element furnace include additional $K$ West and $K$ East damaged fuel elements following completion of the post CVD staging tests. Therefore, the decision was made to utilize an instrumented container capable of controlled temperatures to $150{ }^{\circ} \mathrm{C}$ with continuous pressure measurement capability and the ability to remove gas samples periodically.

The two elements selected for these two tests are 7913M Number 6 with a bottom breach and $6743 \mathrm{U}$ Number 2 with mid element cracks and a top breach (Lawrence 1997). This selection deviates from the previous elements selected for these tests (Lawrence 1998b). The recent requirements for the oxidation tests (Section 2.1) required a change in the assignment of the elements from the existing inventory.

\subsection{SERIES II DRYING TESTS}

Three additional damaged $K$ West fuel elements will be dried to confirm the behavior noted from the first series of drying tests (Lawrence 1997). These tests wi11, however, not be conducted in chronological order. The first Series II drying test will be a repeat of furnace Run 7 with a severely damaged element to confirm the behavior noted in drying a severely damaged element. This test is expected to confirm the bounding behavior noted for 
moisture and hydrogen release from the severely damaged elements. This test is to be placed chronologically as Run 11 after the oxidation tests and before the post CVD staging tests.

Following completion of the post CVD staging tests the two remaining damaged $K$ West elements will be dried to confirm the behavior of elements with intermediate levels of damage. The three drying tests, i.e., Runs 11, 14, and 15 will duplicate the current CVD process drying cycle as much as possible within the limitations of the experimental equipment.

These two final tests provide one opportunity to explore different areas of drying behavior noted in the first series, if necessary. These tests will most likely be eliminated if there are no outstanding questions to be addressed with the drying of the $K$ West fuel and the confirmation test of severe damage, i.e., Run 11, shows similar behavior when compared to Run 7 .

\subsection{PHASE II TEST MATRIX}

The overall Phase II test matrix is summarized in Table 2. This table includes the oxidation matrix (Table 1) with the other two groups of tests that make up the Phase II whole element furnace tests. The status and planned uses for the complete inventory of $K$ West damaged fuel is summarized in Table 3 .

Table 2. Phase II Test Matrix for 0xidation, Post Cold Vacuum Drying Staging, and Drying Studies.

\begin{tabular}{|c|c|c|c|}
\hline $\begin{array}{l}\text { Furnace } \\
\text { Run } \\
\text { Number }\end{array}$ & $\begin{array}{c}\text { Fuel Element } \\
\text { Number }\end{array}$ & Fuel Type & Test Objectives \\
\hline 8 & Not applicable & $\begin{array}{l}\text { Sections of an unirradiated } \\
N \text { Reactor inner element }\end{array}$ & $\begin{array}{l}\text { System calibration with } \\
\text { unirradiated fuel with a known } \\
\text { surface area }\end{array}$ \\
\hline 9 & $\begin{array}{l}\text { 0309M (Number 6) } \\
\text { Bottom half }\end{array}$ & Breached lower half & $\begin{array}{l}\text { 0xidation with minimal exposed } \\
\text { fuel }\end{array}$ \\
\hline 10 & $6513 \mathrm{M}$ (Number 1) & Severe fuel damage & $\begin{array}{l}\text { Oxidation with an extended } \\
\text { amount of exposed fuel }\end{array}$ \\
\hline 11 & 65130 (Number 6 ) & Severe damage & Confirmation of Run 7 behavior* \\
\hline 12 & $7913 \mathrm{M}$ (Number 6) & Bottom breach & Post CVD staging test \\
\hline 13 & $6743 \mathrm{U}$ (Number 2) & $\begin{array}{l}\text { Top breach with mid-element } \\
\text { cracks }\end{array}$ & Post CVD staging test \\
\hline 14 & $6743 \mathrm{M}$ (Number 6) & Top breach & Confirmation of Run 4 behavior* \\
\hline 15 & $1164 U$ (Number 1) & Mid-element cracks & Confirmation of Run 6 behavior* \\
\hline
\end{tabular}

*Duplicate current CVD process conditions. 
Table 3. K West Fuel Element Inventory.

\begin{tabular}{|c|c|c|c|c|c|}
\hline $\begin{array}{l}\text { Element } \\
\text { Number }\end{array}$ & $\begin{array}{l}\text { Type } \\
0, I^{*}\end{array}$ & $\begin{array}{c}\text { Extent of } \\
\text { Damage }\end{array}$ & $\begin{array}{c}\text { Outer Surface } \\
\text { Condition }\end{array}$ & Planned Examinations & Status \\
\hline \multicolumn{6}{|c|}{ K West Elements Second Campaign ( 15 outer and 1 Inner) } \\
\hline $0161 M(2)$ & 0 & Top breach & $\begin{array}{l}\text { White coating } \\
\text { flaking }\end{array}$ & Coating examinations & Coating removed \\
\hline $2667 \cup(3)$ & 0 & Top breach & $\begin{array}{l}\text { Orange } \\
\text { coating }\end{array}$ & Coating examinations & Coating removed \\
\hline $5744 \cup(4)$ & 0 & Top breach & $\begin{array}{l}\text { Gray/white } \\
\text { coating }\end{array}$ & $\begin{array}{l}\text { Furnace test Phase I } \\
\text { (Run 4) }\end{array}$ & Test complete \\
\hline $6743 M(6)$ & 0 & Top breach & $\begin{array}{l}\text { Gray/white } \\
\text { coating }\end{array}$ & $\begin{array}{l}\text { Furnace test Phase II } \\
\text { (Run 14) }\end{array}$ & \\
\hline $6603 M(5)$ & 0 & Bottom breach & $\begin{array}{l}\text { Gray/white } \\
\text { coating }\end{array}$ & $\begin{array}{l}\text { Furnace test } \\
\text { Phase I/(Run 5) }\end{array}$ & Test complete \\
\hline $7913 M(6)$ & 0 & Bottom breach & $\begin{array}{l}\text { Gray/white } \\
\text { coating }\end{array}$ & $\begin{array}{l}\text { Furnace test Phase II } \\
\text { (Run 12) }\end{array}$ & \\
\hline $6743 \cup(6)$ & 0 & $\begin{array}{l}\text { Bottom breach } \\
\text { mid-cracks }\end{array}$ & $\begin{array}{l}\text { Gray/white } \\
\text { coating }\end{array}$ & $\begin{array}{l}\text { Surface/subsurface } \\
\text { sludge deposits }\end{array}$ & $\begin{array}{l}\text { Element examined } \\
\text { coating removed }\end{array}$ \\
\hline $7913 \cup(4)$ & 0 & $\begin{array}{l}\text { Bottom breach } \\
\text { mid-cracks }\end{array}$ & $\begin{array}{l}\text { Gray/white } \\
\text { coating }\end{array}$ & $\begin{array}{l}\text { Surface/subsurface } \\
\text { sludge deposits }\end{array}$ & $\begin{array}{l}\text { Element examined } \\
\text { coating removed }\end{array}$ \\
\hline $1164 M(5)$ & 0 & Mid-cracks & $\begin{array}{l}\text { Gray/white } \\
\text { coating }\end{array}$ & $\begin{array}{l}\text { Furnace test Phase I } \\
\text { (Run 6) }\end{array}$ & Test complete \\
\hline $1164 U(1)$ & 0 & Mid-cracks & $\begin{array}{l}\text { Gray/white } \\
\text { coating }\end{array}$ & $\begin{array}{l}\text { Furnace Test Phase II } \\
\text { (Run 15) }\end{array}$ & \\
\hline $6743 \cup(2)$ & 0 & $\begin{array}{l}\text { Top breach } \\
\text { mid-cracks }\end{array}$ & $\begin{array}{l}\text { Gray/white } \\
\text { coating }\end{array}$ & $\begin{array}{l}\text { Furnace test Phase II } \\
\text { (Run 13) }\end{array}$ & \\
\hline $2560 M(6)$ & 0 & Severe Damage & $\begin{array}{l}\text { Gray/white } \\
\text { coating }\end{array}$ & $\begin{array}{l}\text { Furnace test Phase I } \\
\text { (Run } 7 \text { ) }\end{array}$ & Test complete \\
\hline $6513 \cup(6)$ & 0 & Severe Damage & $\begin{array}{l}\text { Gray/white } \\
\text { coating }\end{array}$ & $\begin{array}{l}\text { Furnace test Phase II } \\
\text { (Run 11) }\end{array}$ & \\
\hline $6513 U(6)$ & I & Unknown & Unknown & None & \\
\hline $6513 M(1)$ & 0 & Severe damage & $\begin{array}{l}\text { Gray/white } \\
\text { coating }\end{array}$ & $\begin{array}{l}\text { Furnace test Phase II } \\
\text { (Run } 10 \text { ) }\end{array}$ & \\
\hline $0309 M(6)$ & 0 & $\begin{array}{l}\text { Broke in half } \\
\text { (Top half) }\end{array}$ & $\begin{array}{l}\text { Gray/white } \\
\text { coating }\end{array}$ & $\begin{array}{l}\text { Furnace test } \\
\text { Phase I/(Run 3) }\end{array}$ & Test complete \\
\hline $0309 M(6)$ & 0 & $\begin{array}{l}\text { Broke in half } \\
\text { (bottom half) }\end{array}$ & $\begin{array}{l}\text { Gray/white } \\
\text { coating }\end{array}$ & $\begin{array}{l}\text { Furnace test Phase II } \\
\text { (Run 9) }\end{array}$ & \\
\hline
\end{tabular}

* $\mathrm{I}=$ Inner, 0 = Outer elements. 


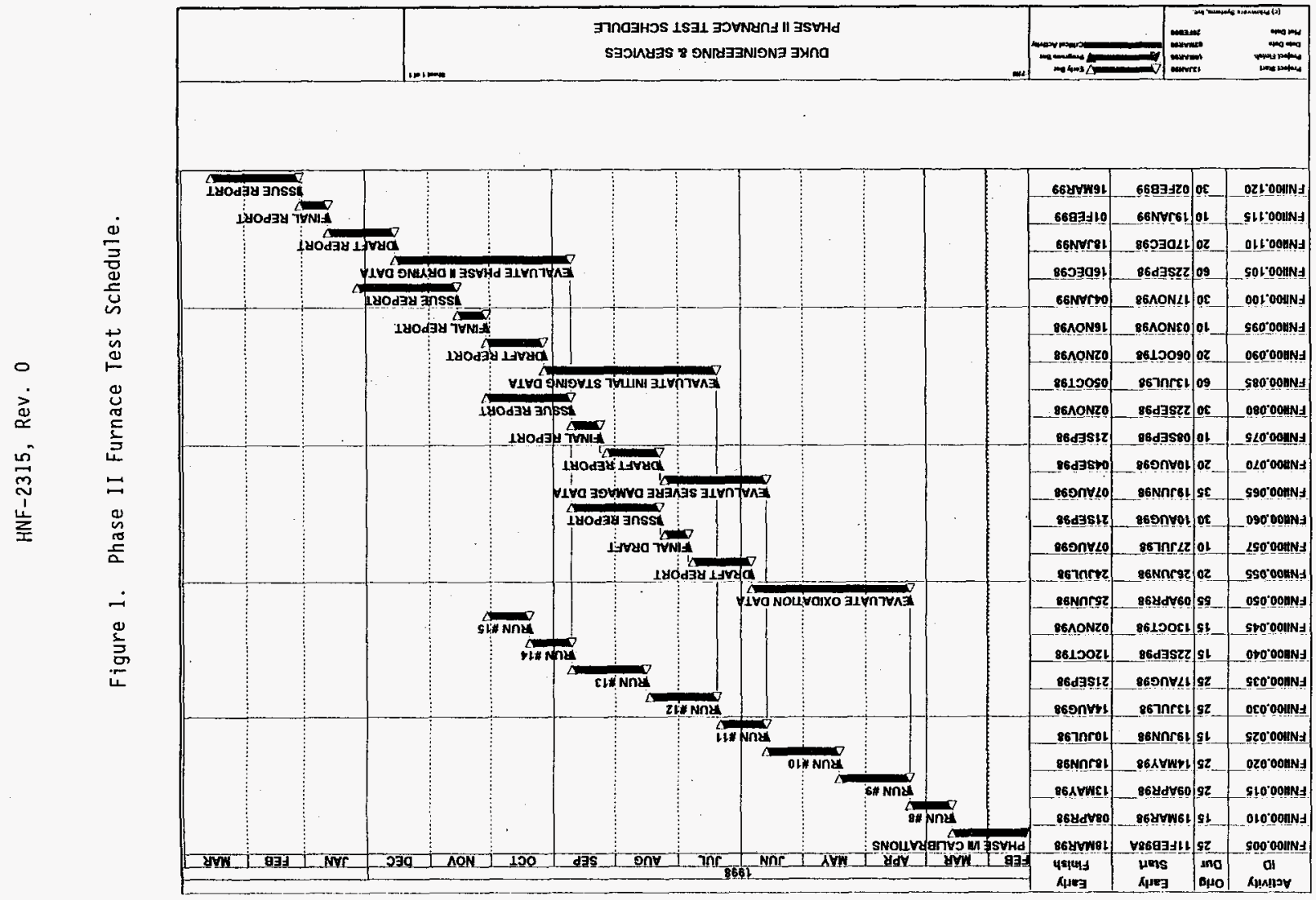




\subsection{PHASE II TEST SCHEDULE}

The overall Phase II schedule is summarized in Figure 1. Following the completion of the Phase I testing with Run 7 a series of equipment calibrations are necessary as well as some modification for the moist inert measurements. These activities include calibration of the Mass Spectrometer and Gas Chromatograph, recovery of the particulate filters for a survey of the radioactivity present and possible examinations, installation of a high moisture level probe, addition of a needed moisture trap, and the addition of thermocouples to monitor the element surface temperature for the oxidation measurements.

The Phase II testing schedule will extend into the first quarter of FY 1999. If the final two tests, i.e., Runs 14 and 15 , are not conducted then the Phase II testing could be completed in FY 1998 if sufficient funds are provided to support these tests.

\subsection{PHASE III FURNACE TESTING}

The third phase of the whole element furnace testing will include the $K$ East damaged fuel elements (Lawrence 1996). A total of six elements were identified for whole element drying studies. These measurements will be focused on the question, "does the $K$ East fuel behave similarly to the $K$ West fuel under drying conditions or does the $K$ East damaged fuel represent a different population?" The specific testing of these elements are outside the scope of this strategy and will be addressed in a separate strategy document following the planned Phase II testing. 


\subsection{REFERENCES}

Abrefah, J., 1998, Dry Air Oxidation Kinetics of $K$ Basin Spent Nuclear Fuel, PNNL-11786, Pacific Northwest National Laboratory, Richland, Washington.

Huang, F. F., (FDNW), 1998, Pressurization of Whole Element Canisters During Staging, HNF-2047, Rev. 0, Duke Engineering \& Services Hanford, Richland, Washington.

Klinger, G. S., 1998, Drying Results of $K$ Basin Fuel Element $5744 U$ (Run 4), PNNL-11821, Pacific Northwest National Laboratory, Richland, Washington.

Lawrence, L. A., 1998a, Fuel Surface Area, HNF-SD-SNF-017, Rev. 1, Duke Engineering \& Services Hanford, Inc., Richland, Washington.

Lawrence, L. A., 1998b, Letter to S. C. Marschman, PNNL, "Elements Selected for Post Cold Vacuum Drying Staging Tests, "DESH-9850866, Duke Engineering \& Services Hanford, Inc., Richland, Washington.

Lawrence, L. A., 1997, Strategy for Examination of the Fifteen $K$ West Basin Fuel Elements, HNF-SD-SNF-SP-018, Rev. 0, Duke Engineering \& Services Hanford, Inc., Richland, Washington.

Lawrence, L. A., 1996, Strategy for Examination of the Initial Nine $K$ East Basin Fue 7 Elements, WHC-SD-SNF-SP-014, Rev. 0, Westinghouse Hanford Company, Richland, Washington.

01 iver, B. M., 1998, Drying Results of $K$ Basin Fuel Element 0309M (Run 3), PNNL-11820, Pacific Northwest National Laboratory, Richland, Washington.

Pajunen, A. L., 1998, "Status of Reaction Rate Information for the Spent Nuclear Fuel Project," Undocumented, January 28, 1998, Duke Engineering \& Services Hanford, Inc., Richiand, Washington.

Ritter, G. A., (FDNW), 1998a, System Design Description for the Whole Element Furnace Testing System, PNNL-11807, Pacific Northwest National Laboratory, Richland, Washington.

Ritter, G. A., (FDNW), 1998b, Post Cold Vacuum Drying Storage Container Design Review Package, undocumented, Duke Engineering \& Services Hanford, Richland, Washington. 


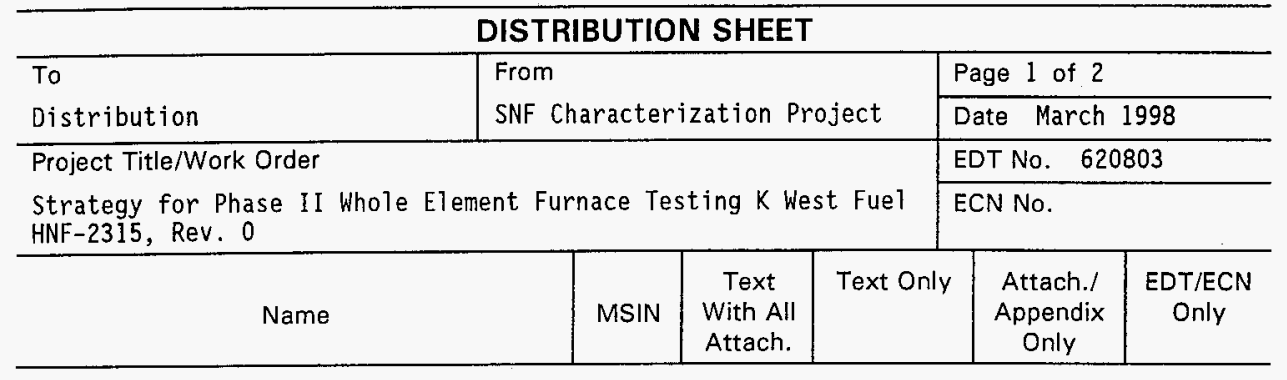

Fluor Daniel Hanford, Inc.
E. W. Gerber
R3-11 X

Duke Engineering \& Services Hanford, Inc.

C. J. Alderman

R. B. Baker

D. W. Bergmann

A. E. Bridges

S. A. Chastain

D. R. Duncan

J. R. Frederickson

S. L. Hecht

L. A. Lawrence

B. J. Makenas

R. P. Omberg

A. L. Pitner

A. M. Segrest

E. J. Shen

D. W. Smith

J. A. Swenson

D. J. Trimble

J. H. Wicks

SNF Project Files

Fluor Daniel Northwest

L. J. Garvin

Lockheed Martin Services. Inc.

$\begin{array}{ll}X 3-85 & X \\ H 0-40 & X \\ X 3-79 & X \\ H O-40 & X \\ H O-40 & X \\ \text { R3-86 } & X \\ \text { R3-86 } & X \\ H O-40 & X \\ H O-40 & X \\ H O-40 & X \\ H O-40 & X \\ H 0-40 & X \\ \text { R3-11 } & X \\ \text { X3-75 } & X \\ \text { R3-26 } & X \\ \text { R3-11 } & X \\ H 0-40 & X \\ \text { R3-11 } & X \\ \text { R3 }-11 & X\end{array}$

R3-26 X

B1-07 $X$ 


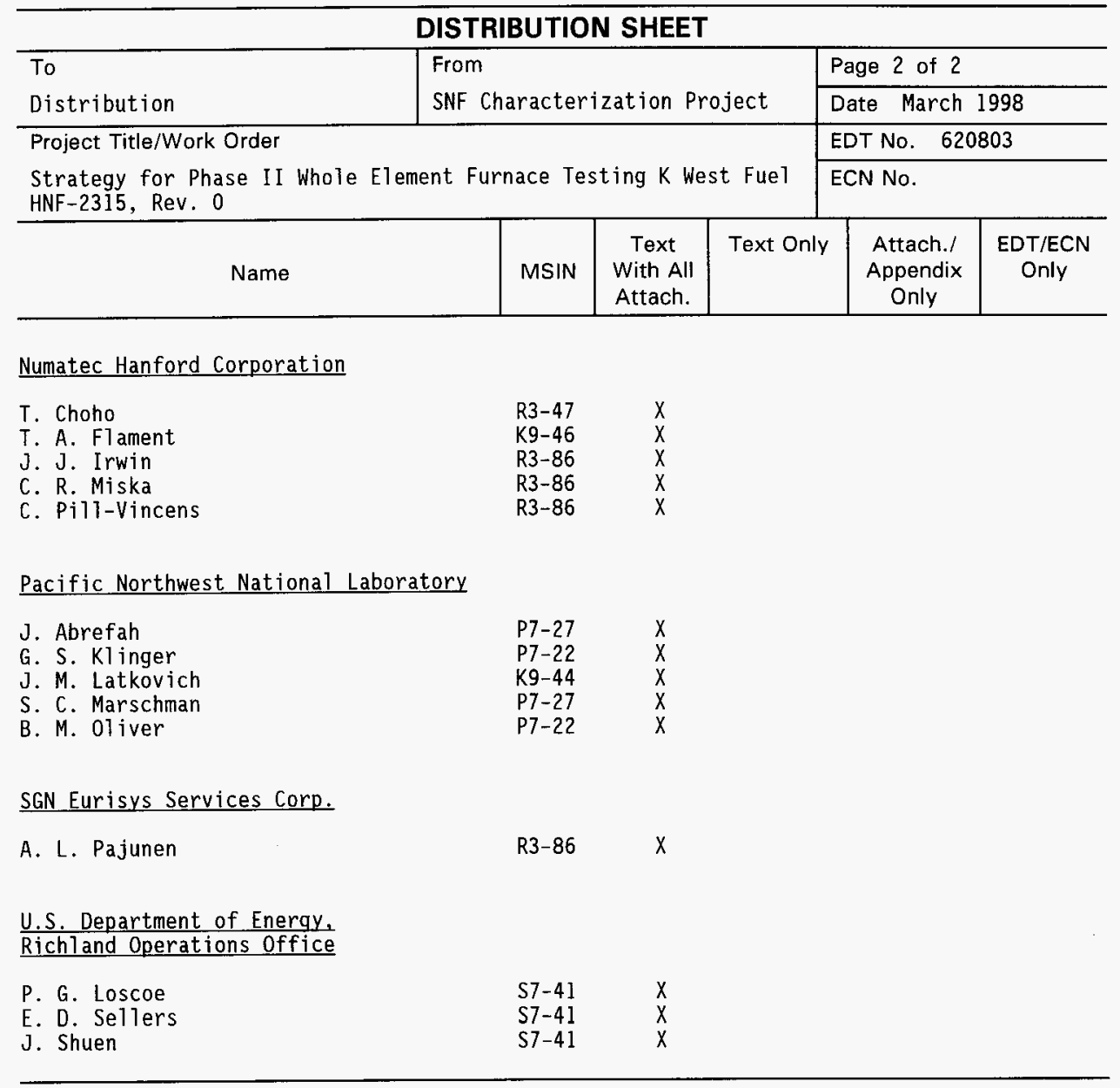

